\title{
Effect of Methyl Mercury on the Cerebellar Cortex of Rats and the Possible Neuroprotective Role of Mesenchymal Stem Cells Conditioned Medium. Histological and Immunohistochemical Study
}

\author{
Nahla El-Eraky El-Azab ${ }^{1 *}$, Abeer M. El-Mahalaway ${ }^{1}$ and Dina Sabry²
}

${ }^{1}$ Departments of Histology and Cell Biology, Faculty of Medicine, Benha University, Benha, Egypt

${ }^{2}$ Department of Medical Biochemistry and Molecular Biology, Faculty of Medicine, Cairo University, Cairo, Egypt

\begin{abstract}
Background: Methyl mercury (Me $\mathrm{Hg}$ ) is an environmental toxin associated with many serious neurological disorders. Conditioned Medium (CM) derived from Mesenchymal Stem Cells (MSCs) is a novel promising approach for the treatment of nervous system damage and various diseases.
\end{abstract}

Objective: The aim of this research is to assess the consequence of $\mathrm{Me} \mathrm{Hg}$ on the rats' cerebellar cortex and the potential neuroprotective effect of MSCs - CM.

Materials and methods: Forty adult male albino rats were divided into four groups: Group I: control rats; Group II: $\mathrm{Me} \mathrm{Hg}$ chloride treated rats; Group III: Me Hg chloride and DMEM treated rats; Group IV: CM treated rats after injection with $\mathrm{Me} \mathrm{Hg}$ chloride. Cerebellar specimens were taken and handled for histological and immunohistochemical techniques. Morphometrical studies and statistical analysis were performed.

Results: Groups II and III showed various changes such as neuronal degeneration and apoptosis. The mean number of Purkinje cells was significantly decreased $(P<0.01)$, while Glial Fibrillary Acidic Protein (GFAP) immunostaining was significantly increased $(P<0.01)$ in the neuroglial cells. Ultrastructural examination showed thinning and apparent decrease in the number of myelinated nerve axons. Shrunken Purkinje cells were observed with irregular nuclei, heterogenous cytoplasm, and disrupted mitochondria. Group IV showed improvement of the histological and electron microscopic changes defined in groups II and III.

Conclusion: $\mathrm{Me} \mathrm{Hg}$ exposure led to degenerative changes on cerebellar cortex. MSCs - CM is a very promising approach and has neuroprotective effects.

Keywords: Cerebellar cortex; Methyl mercury; Neurotoxicity; Conditioned medium

Abbreviations: Me Hg: Methyl Mercury; CM: Conditioned Medium; MSCs: Mesenchymal Stem Cells; GFAP: Glial Fibrillary Acidic Protein; DMEM: Dulbecco's Modified Eagle Medium; Rpm: Round Per Minute; PBS: Phosphate-Buffered Saline

\section{Introduction}

Cerebellum has a vital role in the incorporation of sensory functions and harmony of motor functions; any deformation or lesion in the cerebellum leads to damage of the motor coordination and impaired balance [1,2]. Environmental contamination is a universal problem. Heavy metals are naturally occurring elements in Earth's crust and are present in different concentrations in all ecosystems. They are considered the principle chemical pollutants as they cannot be degraded or destroyed. They have a susceptibility to accumulate in the soil, water and food chain $[3,4]$.

Mercury is a naturally occurring metal existing in the environment in organic and inorganic forms. It is used in medicine as a topical antiseptic and disinfectant, in agriculture as a fungicide and in chemistry to yield other mercury compounds [5]. $\mathrm{MeHg}$ is the greatest toxic type of $\mathrm{Hg}$ and its poisoning can result from inhalation, ingestion, or dermal absorption. Once absorbed, it distributes extensively to all tissues $[4,6]$.

Continuous environmental and work-related exposure to $\mathrm{Me}$ $\mathrm{Hg}$ can cause many serious health hazards such as neurological and developmental disorders, liver, kidneys respiratory, immune, dermatologic, reproductive and gastrointestinal toxicity, ulceration, and haemorrhage [7-9].
MSCs originate from the mesoderm and the ectoderm throughout early embryonic development and are found in several kinds of tissues and organs $[10,11]$. They form a promising therapeutic line for neurodegenerative diseases. However, MSCs have drawbacks as they do not persist in the host injured tissue and have a limited ability to substitute lost cells. Nowadays, MSCs - CM, rather than MSCs transplantation has been commonly tried in regenerative medicine, treatment of injuries of the nervous system and various diseases such as alopecia, acute and chronic hind limb ischemia, acute and chronic wound healing, myocardial infarction, acute liver injury/failure, cerebral injury/ischemia/stroke, spinal cord injury, lung injury and bone defect [12-14]. MSCs - CM contains many growth factors, cytokines and also exosomes- like microvesicles derived from the MSCs $[15,16]$.

The aim of this study is to evaluate the consequence of $\mathrm{Me} \mathrm{Hg}$ on the cerebellar cortex of rats and the potential neuroprotective effect of MSCs-CM.

*Corresponding author: Nahla El-Eraky El-Azab, Department of Histology and Cell Biology, Faculty of Medicine, Benha University, Benha, Egypt, Tel: +201027636357; E-mail: nahla.Eleraky@fmed.bu.edu.eg

Received June 01, 2018; Accepted June 18, 2018; Published June 22, 2018

Citation: El-Azab NEE, El-Mahalaway AM, Sabry D (2018) Effect of Methyl Mercury on the Cerebellar Cortex of Rats and the Possible Neuroprotective Role of Mesenchymal Stem Cells Conditioned Medium Histological and Immunohistochemical Study. Stem Cell Res Ther 8: 430. doi: 10.4172/2157-7633.1000430

Copyright: (C) 2018 El-Azab NEE, et al. This is an open-access article distributed under the terms of the Creative Commons Attribution License, which permits unrestricted use, distribution, and reproduction in any medium, provided the original author and source are credited. 
Citation: El-Azab NEE, El-Mahalaway AM, Sabry D (2018) Effect of Methyl Mercury on the Cerebellar Cortex of Rats and the Possible Neuroprotective Role of Mesenchymal Stem Cells Conditioned Medium. Histological and Immunohistochemical Study. Stem Cell Res Ther 8: 430. doi: 10.4172/2157-7633.1000430

Page 2 of 11

\section{Materials and Methods}

\section{Used chemicals}

Me Hg chloride is obtained from Sigma Aldrich Company, CAS no. 115-09-03. It was white crystalline powder and was liquefied in physiological saline.

\section{Isolation and culture of BMSCs}

BMSCs were isolated from bone marrow of rats following very restricted sterile conditions. The femurs and tibiae of the rats were carefully disconnected from the nearby tissues. The epiphyses of both ends of the bones were removed using disinfected sharp cutters. A sterilized syringe, containing $2 \mathrm{ml}$ of Dulbecco's Modified Eagle Medium (DMEM) was introduced into one end of the bones to eject the marrow masses from the opposite ends of bones to be collected into sterile tubes. The collected bone marrow was flushed with DMEM and centrifuged at $1500 \mathrm{rpm}$ (round per minute) for $6 \mathrm{~min}$. The supernatant was removed and complete culture medium (CCM) was added to the formed cell pellets. CCM was composed of DMEM, $5 \%$ sodium bicarbonate, $10 \%$ fetal bovine serum, and $1 \%$ penicillin/ streptomycin (all bought from Lonza Company, Switzerland). The mixture of complete culture medium and bone marrow was transferred into tissue culture flasks and then incubated at $37^{\circ} \mathrm{C}$ in a humidified $5 \% \mathrm{CO}_{2}$ incubator. The medium containing the non-adherent cells was removed, and the adherent cultured cells were washed twice with Phosphate-Buffered Saline (PBS). The adherent cells were detached by adding $1 \mathrm{ml}$ of $0.25 \%$ trypsin/EDTA solution to the tissue culture flask for $5 \mathrm{~min}$. CCM was further added to the trypsinized cells to prevent any additional residue of trypsin/EDTA solution. BMSC at third passage were used for the preparation of the CM [14].

\section{Characterization of cultured BMSCs}

Morphological characterization of the adherent spindle shaped BMSCs was performed on the 8th day of the culture using inverted microscope Leica DM IL LED with camera Leica DFC295. Further characterization was done by flow cytometry (Beckman Coulter). BMSCs display positivity for CD90 and CD105 and negativity for CD34 [17].

\section{Preparation of the MSCs - CM}

BMSCs at $80 \%$ confluence were washed thrice with PBS and then seeded at density of $3 \times 10^{5}$ cells $/ \mathrm{ml}$ in 24 well plates containing serumfree DMEM culture medium. The CM was aspirated out and collected after $48 \mathrm{hrs}$. Then, it was centrifuged at $1500 \mathrm{rpm}$ for $5 \mathrm{~min}$. The supernatants were recentrifuged at $3000 \mathrm{rpm}$ for $4 \mathrm{~min}$ and then filtered (through $0.20 \mu \mathrm{m}$ sterile syringe filter (Corning, USA)) and the second supernatants were collected [18]. The mean protein concentration of $\mathrm{CM}$ was of $1.3-1.6 \mathrm{mg} / \mathrm{ml}$.

\section{Animals}

Forty adult male rats of average weight $150-200 \mathrm{~g}$ were utilized in this study. Rats were brought from the animal house unit, Moshtohor Faculty of Veterinary Medicine, Benha University. They were housed in animal cages at room temperature $\left(25 \pm 1^{\circ} \mathrm{C}\right)$ and relative humidity $(55 \pm 5)$ and nourished balanced diet and water ad libitum. All ethical rules for the care and use of laboratory animals were followed. The experimental protocol was approved through the Institutional Animal Care Committee of Benha University, Benha, Egypt.

\section{Experimental design}

Animals were divided equally into four groups $(n=10)$ :

- Group I (control group): Animals of this group were additionally subdivided equally into two subgroups.

Subgroup Ia: Rats were injected subcutaneously only once with physiological saline.

Subgroup Ib: Rats were given a single dose of $0.5 \mathrm{ml}$ PBS into caudal vein.

- Group II (Me $\mathrm{Hg}$ treated group): Rats were injected subcutaneously once with methyl mercuric chloride,liquified in physiological saline at a dose of $25 \mathrm{mg} / \mathrm{kg}$ [19].

- Group III (Me Hg and DMEM treated group): Rats were injected with methyl mercuric chloride as described in group II. Three hours later, animals were subjected to a single dose of filtered serumfree DMEM into caudal vein at dose of $0.5 \mathrm{ml} /$ rat [20].

- Group IV (CM treated group): Rats were injected with methyl mercuric chloride as in group II. Three hours later, rats were injected with single dose of the CM into caudal vein at a dose of $0.5 \mathrm{ml} /$ rat [21]. All rats were sacrificed after one week from commencement of experiment after ether inhalation.

\section{Light microscopic studies}

Samples from cerebellum of each animal were dissected and fixed immediately in $10 \%$ neutral-buffered formalin. Paraffin sections (4-5 $\mu \mathrm{m}$ thick) were prepared, processed and stained with $\mathrm{H} \& \mathrm{E}$ stain for the histological details of the cerebellar cortex [22]. Other sections were placed on positively charged slides for immunohistochemical detectionof GFAP [23].

\section{Immunohistochemistry studies}

Immunohistochemical staining for detecting of GFAP antibody: the primary monoclonal antibody used was a rabbit polyclonal antibody (Lab Vision Corporation Laboratories, USA; Cat. No. OPA1-06100). The cellular site of the reaction was brown colour in the cytoplasm of glial cells such as astrocytes.

Immunohistochemical study was conducted using the avidinbiotin peroxidase method, followed by Diaminobenzidine (DAB) (Dakopatts, Glostrup, Denmark) added to slides as a chromogen; then, the slides were washed with distilled water. Later, the sections were counterstained with hematoxylin. For the negative control, the specific primary antibody was replaced with PBS. The positive control for GFAP was a section from the brain.

\section{Transmission electron microscopic study}

Small pieces $\left(1 \mathrm{~mm}^{3}\right)$ from the cerebellum were taken and ultrathin sections were prepared according to [24] in Tanta EM Unit, Faculty of Medicine, Tanta University, Tanta, Egypt. Sections were photographed using a transmission electron microscope JEM-2100 (Jeol, Tokyo, Japan) at the Faculty of Medicine, Benha University.

\section{Morphometric and statistical analysis}

Using a Leica Qwin 500 image analysis computer system (Leica Microsystems Ltd, Cambridge, UK) at the Pathology Department, Faculty of Medicine, Cairo University, ten slides from each group were measured. All Purkinje cells were counted along the Purkinje cells monolayer in 10 cerebellar lobules of each H\&E section using light 
Citation: El-Azab NEE, El-Mahalaway AM, Sabry D (2018) Effect of Methyl Mercury on the Cerebellar Cortex of Rats and the Possible Neuroprotective Role of Mesenchymal Stem Cells Conditioned Medium. Histological and Immunohistochemical Study. Stem Cell Res Ther 8: 430. doi: 10.4172/2157-7633.1000430

Page 3 of 11

microscopy at $400 \times$ magnification. The average value for the ten lobules was calculated for each section.

The mean area percentage of positive GFAP immunoreactivity was assessed. The process was performed using GFAP immunostained sections in 10 non-overlapping fields of each section at $400 \times$ magnification.

All the data collected from the experiment were recorded and analyzed using IBM SPSS software for Windows, Version 20 (IBM Corp., Armonk, NY, USA). One-way analysis of variance (ANOVA) with post hoc Scheffe's test was applied to compare differences among the groups. The differences were considered significant at $\mathrm{P}<0.01$.

\section{Result}

\section{Light microscopy results}

\section{H\&E}

- $\quad$ Group I (control groups): All the subgroups showed normal histological picture of cerebellum. Each cerebellar folium contained a central core of white matter covered by an outer cortical gray matter named cerebellar cortex. The gray matter formed of three layers, an external molecular, middle Purkinje cell and inner granular layers (Figure 1a). The outer molecular layer showed glial cells such as superficial stellate and deep basket, while the middle Purkinje cell layer had large pyriformPurkinje neuronal cells with clear vesicular nuclei and a basophilic cytoplasm arranged in a single row and surrounded by Bergmann protoplasmic astrocytes. Inner granular layer had aggregation of small deeply stained granule cells with pale non-cellular areas in between cells called the cerebellar island (Figure 1b).

- $\quad$ Group II (Me Hg treated group) and group III (Me Hg and DMEM treated group): These groups showed marked histological alterations as areas of degeneration in the molecular layer. The Purkinje cells had dark stained nuclei with eosinophilic cytoplasm and some of them are lost leaving empty spaces.Granular layer appeared thin and contained many apoptotic cells with small eccentric nuclei. Moreover, the congested blood vessels were seen (Figures $2 \mathrm{a}, 2 \mathrm{~b}$ and 3 ).

- Group IV (CM treated group): Sections of this group revealed apparently normal histological structure for all layers of the cerebellar cortex. Most of the Purkinje cells regained their normal pyriform

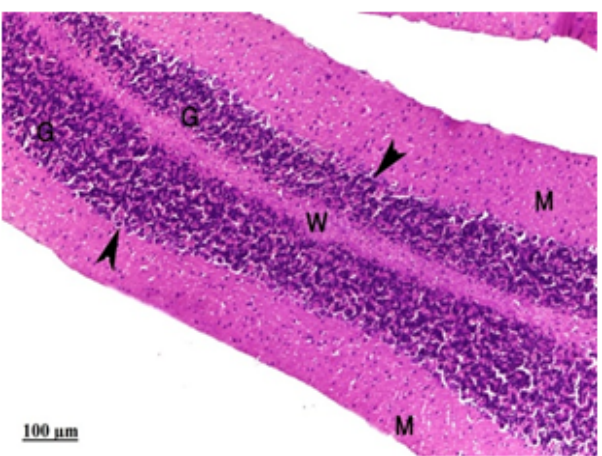

(a)

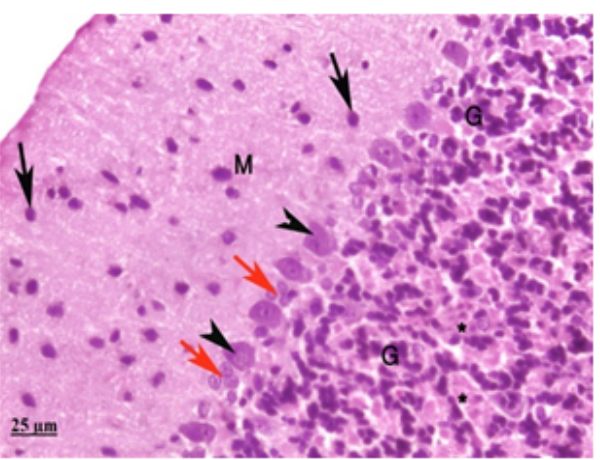

(b)

Figure 1: Photomicrographs of a section in the cerebellar cortex of group I showing: (a) A cerebellar folium with an outer gray matter and innermost white matter (W). The gray matter has an external molecular layer (M), middle Purkinje cell layer ( $\boldsymbol{\Delta}$ arrow heads) and inner granular layer $(\mathrm{G})(\mathrm{H} \& \mathrm{E}, \times 100 \mathrm{scale}$ bar $=100 \mu \mathrm{m})$; (b) The outer molecular layer (M) containing glial cells (black arrow $\uparrow$ ). The middle Purkinje cell layer has large pyriform Purkinje neuronal cells $(\boldsymbol{\Delta}$ arrow heads) and Bergmann protoplasmic astrocytes (red arrow $\uparrow$ ). Inner granular layer shows aggregation of small granule cells (G) with pale areas of the cerebellar island in between $\left(^{*}\right)(\mathrm{H} \& \mathrm{E}, 400 \times$, scale bar $=25 \mu \mathrm{m})$.

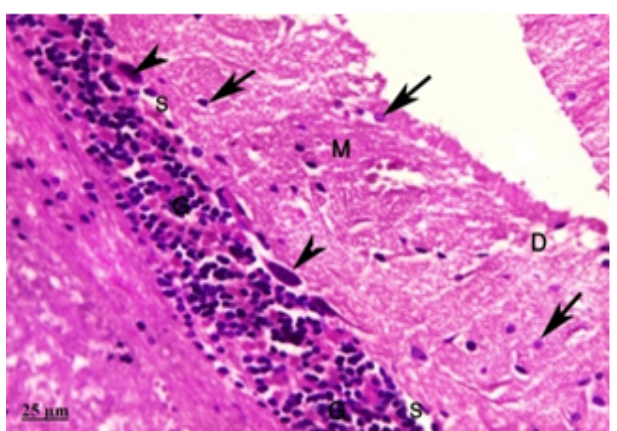

(a)

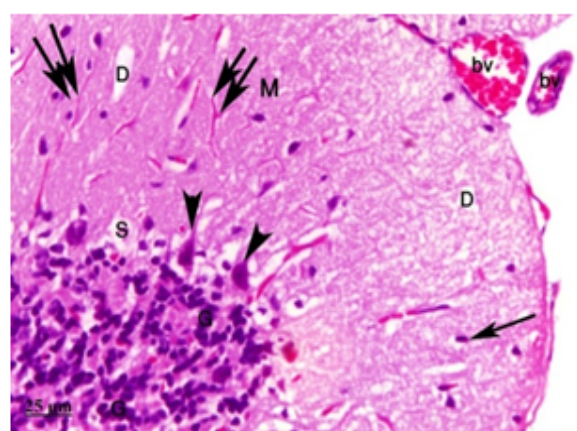

(b)

Figure 2: Photomicrographs of a section in the cerebellar cortex of group II showing: (a) Showing the molecular layer (M) with areas of degeneration (D) and scattered glial cells (black arrow $\uparrow$ ). The Purkinje cells ( $\boldsymbol{\Lambda}$ arrow heads) seem to have dark stained nuclei with eosinophilic cytoplasm and some of them are lost leaving empty spaces (S). Granular layer appears thin and contains many apoptotic cells with small eccentric nuclei (G) (H\&E, $\times 400$, scale bar=25 $\mu$ m); (b) Areas of degeneration (D) in the molecular layer (M) with scattered glial cells (black arrow $\uparrow$ ) and fibers (two arrows $\uparrow \uparrow$ ). The Purkinje cells ( $\boldsymbol{\Lambda}$ arrow heads) appear to have darkly stained nuclei and some of them are lost leaving empty spaces (S). Granular layer shows numerous apoptotic cells with small nuclei (G). Congested blood vessel (bv) is also seen $(H \& E, 400 \times$, scale bar=25 $\mu \mathrm{m})$. 
Citation: El-Azab NEE, El-Mahalaway AM, Sabry D (2018) Effect of Methyl Mercury on the Cerebellar Cortex of Rats and the Possible Neuroprotective Role of Mesenchymal Stem Cells Conditioned Medium. Histological and Immunohistochemical Study. Stem Cell Res Ther 8: 430. doi: 10.4172/2157-7633.1000430

shape with vesicular nuclei and were surrounded by neuroglia cells. No apoptotic cells were noticed in the granular layer (Figure 4).

\section{Toluidine blue}

Group I showed the three different layers of cerebellar cortex. Purkinje cells had large central vesicular nucleus, a prominent dark nucleolus and thick long apical dendrites. Granular layer contained many granule cells with dark stained nuclei and granular chromatin. The cerebellar islands were seen in between granule cells (Figure 5a). Groups II and III revealed areas of degeneration in molecular layer. Some Purkinje cells appeared distorted with darkly stained cytoplasm and ill-defined nuclei, while other cells were lost leaving empty spaces. The granular layer showed some granule cells with deeply stained nuclei and vacuolations of cerebellar island. Neuroglial cells were observed in between granule cells (Figures $5 b$ and $5 c$ ). Group IV apparently regained the normal appearance of molecular, Purkinje cell and granular layers of cerebellar cortex (Figure 5d).

\section{Immunohistochemical results of GFAP}

Group I showed scattered positive GFAP immunoreaction of the neuroglial cells and their processes in the molecular, Purkinje cell and

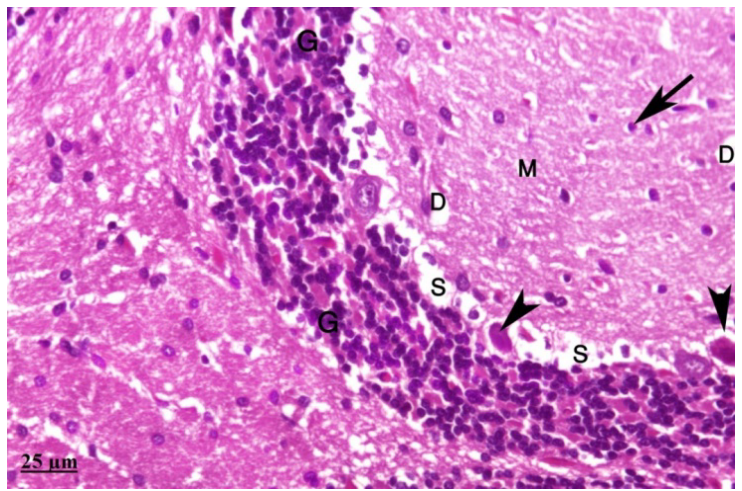

Figure 3: A photomicrograph of a section in the cerebellar cortex of group III showing the molecular layer (M) with areas of degeneration (D) and scattered glial cells (black arrow $\uparrow$ ). Most of the Purkinje cells are lost leaving empty spaces (S), but few cells have darkly stained nuclei ( $\boldsymbol{\Delta}$ arrow heads). Granular layer $(G)$ is thin and shows several apoptotic cells with small nuclei (H\&E, 400×, scale bar=25 $\mu \mathrm{m}$ ).

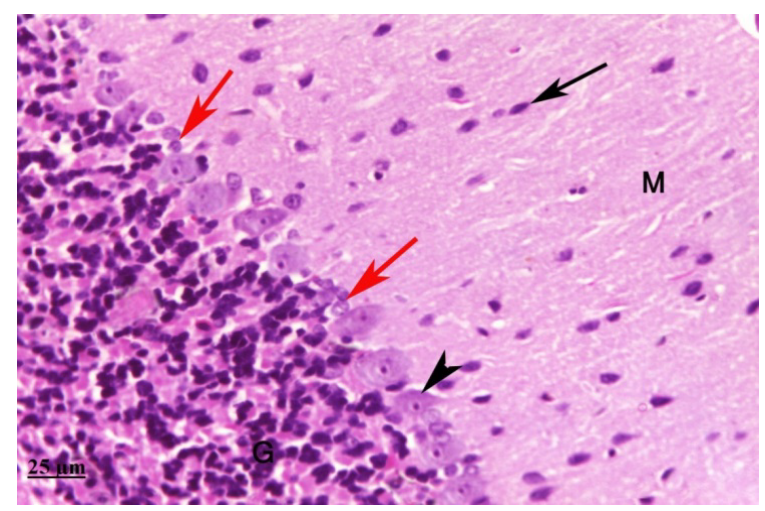

Figure 4: A photomicrograph of a section in the cerebellar cortex of group IV showing the molecular layer (M) with scattered glial cells (black arrow $\uparrow$ ). The cells of the Purkinje cell layer ( $\boldsymbol{\Delta}$ arrow heads) appear to have vesicular nuclei and are surrounded by neuroglia cells (red arrow $\uparrow$ ). Granular layer (G) is of almost normal appearance (H\&E, $400 \times$, scale bar=25 $\mu \mathrm{m})$.

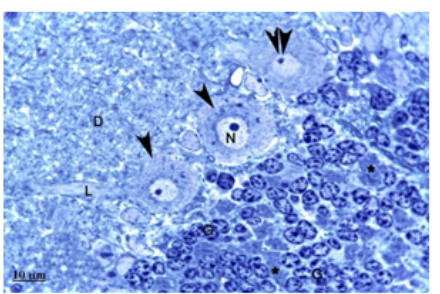

(a)

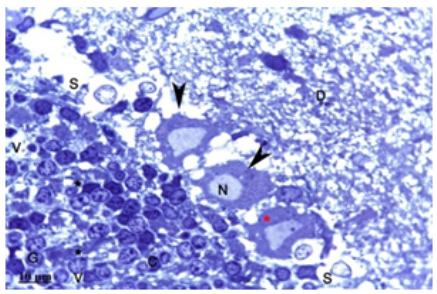

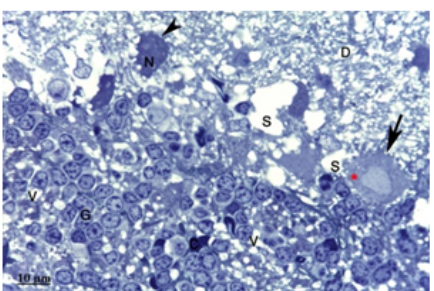

(b)

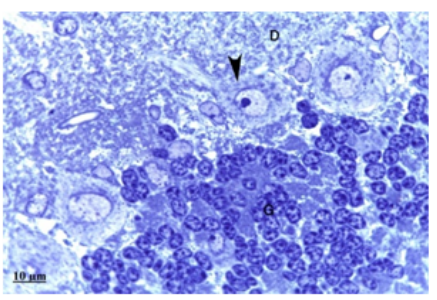

Figure 5: Photomicrographs of semi thin sections in the cerebellar cortex (a) Group I showing the molecular layer (D), the Purkinje cell layer ( $\Delta$ arrow heads) and the internal granular layer $(\mathrm{G})$. Purkinje cells have large central vesicular nucleus $(\mathrm{N})$, a prominent dark nucleolus (two arrow heads) and thick long apical dendrites $(\mathrm{L})$. Granular layer $(\mathrm{G})$ has many granule cells with dark stained nuclei and granular chromatin. The cerebellar islands $\left(^{*}\right)$ are seen in between granule cells (Toluidine blue, $1000 \times$, scale bar=10 $\mu \mathrm{m}$ ); (b) Group II showing areas of degeneration in molecular layer (D). Purkinje cells are distorted ( $\boldsymbol{\Delta}$ arrow head) with ill-defined nuclei $(\mathrm{N})$, others (arrow $\uparrow$ ) have darkly stained cytoplasm (red *) and some of them are lost leaving empty spaces (S). The granular layer reveals some granule cells $(G)$ with darkly stained nuclei. Notice vacuolations $(\mathrm{V})$, cerebellar island $\left(^{*}\right)$ and the presence of neuroglial cells $(C)$ in between granule cells (Toluidine blue, 1000×, scale bar=10 $\mu \mathrm{m}$ ); (c) Group III showing areas of degeneration in molecular layer (D). Purkinje cells layer has irregular Purkinje cells ( $\boldsymbol{\Lambda}$ arrow heads) with small nuclei $(\mathrm{N})$ and darkly stained cytoplasm (red ${ }^{*}$ ) and some of them are lost leaving empty spaces (S). The granular layer displays some granule cells $(G)$ with darkly stained nuclei. Vacuolations (V), disruption of cerebellar island $\left(^{*}\right)$ and the presence of neuroglial cells (c) in between granule cells are observed (Toluidine blue, $1000 \times$, scale bar $=10 \mu \mathrm{m}$ ); (d) Group IV showing regaining of the normal appearance of molecular layer (D), Purkinje cells layer $(\boldsymbol{\Delta}$ arrow head) and granular layer (G) (Toluidine blue, 1000×, scale bar=10 $\mu \mathrm{m}$ ).

granular layers (Figure 6a). Groups II and III demonstrated intense deep brown positive immunoreaction for GFAP in the neuroglial cells and their processes in between the Purkinje cell as well as in molecular and granular layers (Figures $6 \mathrm{~b}$ and $6 \mathrm{c}$ ). Group IV revealed GFAPpositive immunoreaction in the neuroglial cells and their processes of the molecular, Purkinje cell and granular layers of the cerebellum (Figure 6d).

\section{Electron microscopic results}

Molecular layer of the cerebellar cortex from group I showed normal myelinated axons which contained mitochondria and microtubules (Figure 7a). Groups II and III revealed thinning, splitting and apparent decrease in the number of myelinated nerve axons with swollen disrupted mitochondria. Vacuolation was seen between axons (Figures $7 \mathrm{~b}$ and $7 \mathrm{c}$ ). Group IV showed many apparently normal myelinated axons with axoplasm containing mitochondria (Figure 7d).

Purkinje cell layer of the cerebellar cortex from group I showed Purkinje cells with large indented euchromatic nuclei, apparent nucleolus, nuclear membrane and cytoplasm (Figure 8a). A highly magnified Purkinje cell appeared with euchromatic nucleus and nuclear membrane; moreover, their cytoplasm contained tubules of rough endoplasmic reticulum, mitochondria and free ribosomes 
Citation: El-Azab NEE, El-Mahalaway AM, Sabry D (2018) Effect of Methyl Mercury on the Cerebellar Cortex of Rats and the Possible Neuroprotective Role of Mesenchymal Stem Cells Conditioned Medium. Histological and Immunohistochemical Study. Stem Cell Res Ther 8: 430. doi: $10.4172 / 2157-7633.1000430$

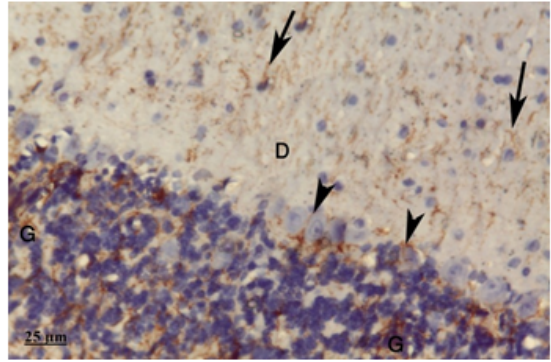

(a)

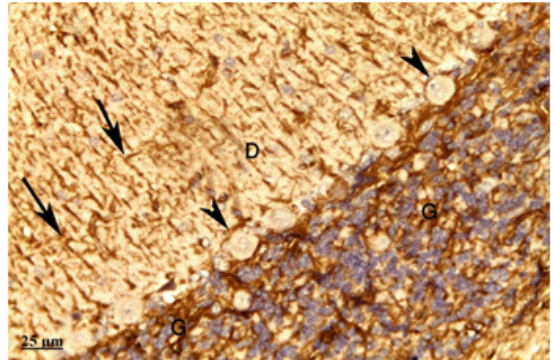

(c)

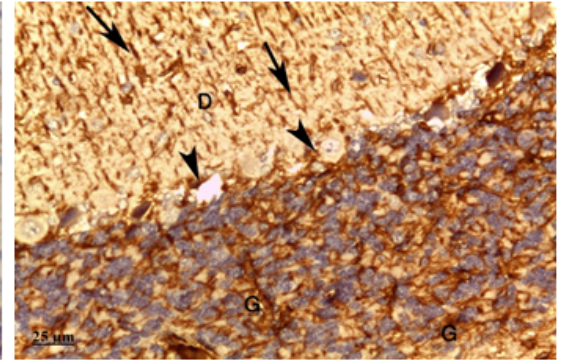

(b)

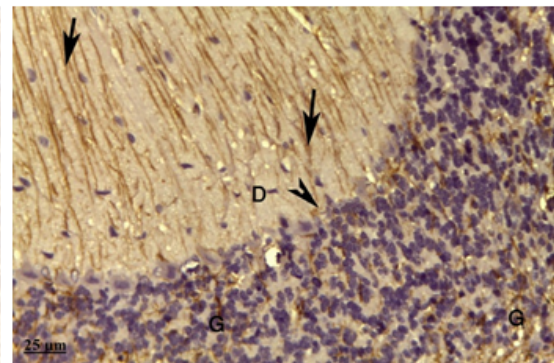

(d)

Figure 6: Photomicrographs of sections in the cerebellar cortex: (a) Group I showing scattered positive GFAP immunoreaction of the neuroglial cells and their processes (black arrow $\uparrow$ ) in the molecular layer (D), Purkinje cells layer ( $\boldsymbol{\Delta}$ arrow heads) and granular layer (G) (Immunostaining for GFAP, $400 \times$, scale bar=25 um); (b) Group II showing abundant deep brown positive immunoreaction for GFAP in the neuroglial cells and their processes (black arrow $\uparrow$ ) in between the Purkinje cell ( $\boldsymbol{\Lambda}$ arrow heads) as well as in molecular (D) and granular (G) layers (Immunostaining for GFAP, 400x, scale bar=25 $\mu$ m); (c) Group III showing intense and abundant positive immunoreaction for GFAP in the neuroglial cells and their thick processes (black arrow $\uparrow$ ) of the molecular layer (D), Purkinje cells layer $(\boldsymbol{\Lambda}$ arrow heads) and granular layer (G) (Immunostaining for GFAP, 400x, scale bar=25 $\mu \mathrm{m}$ ); (d) Group IV showing GFAP-positive immunoreaction in the neuroglial cells and their processes (black arrow $\uparrow$ ) of the molecular (D), Purkinje cells ( $\Delta$ arrow heads) and granular (G) layers (Immunostaining for GFAP, $400 \times$, scale bar=25 $\mu$ m).

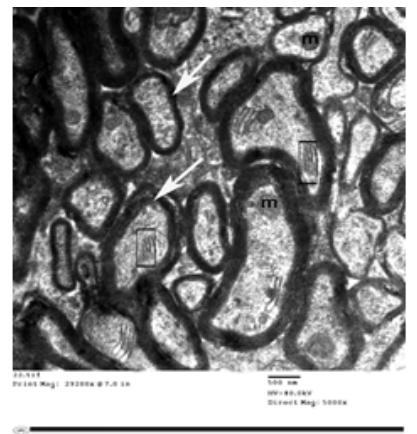

(a)

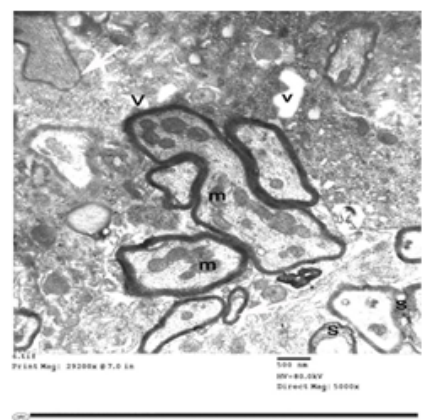

(c)

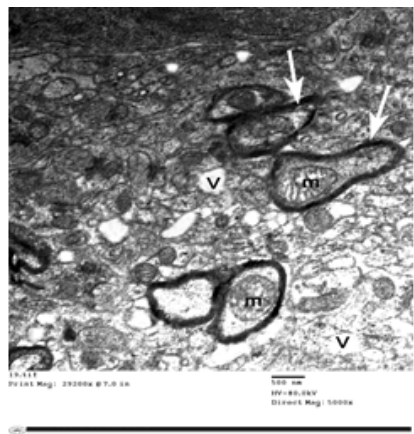

(b)

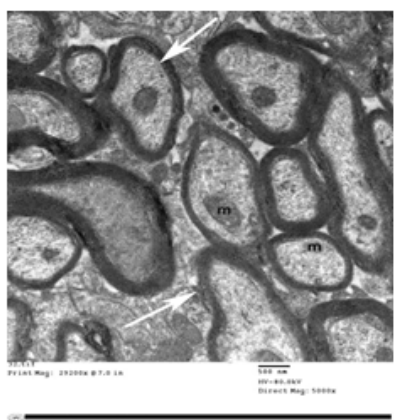

(d)

Figure 7: Transmission electron micrographs of the molecular layer of the cerebellar cortex: (a) Group I showing transverse section in normal myelinated axons (white arrows) containing mitochondria $(\mathrm{m})$ and microtubules (rectangle $\square$ ) (TEM, 5000x); (b) Group II showing thinning and apparent decrease in the number of myelinated nerve axons (white arrows) with swollen disrupted mitochondria (m). Vacuolation between axons (V) is seen (TEM, 5000x); (c) Group III showing splitting (S) and thinning of myelinated nerve axon (white arrows) with distorted irregular mitochondria $(\mathrm{m})$ in some of them. Vacuolations (V) in between the axons are observed (TEM, 5000x); (d) Group IV showing many apparently normal myelinated axons (white arrows). The axoplasm displays mitochondria (m) (TEM, 5000x). 
Citation: El-Azab NEE, El-Mahalaway AM, Sabry D (2018) Effect of Methyl Mercury on the Cerebellar Cortex of Rats and the Possible Neuroprotective Role of Mesenchymal Stem Cells Conditioned Medium. Histological and Immunohistochemical Study. Stem Cell Res Ther 8: 430. doi: $10.4172 / 2157-7633.1000430$

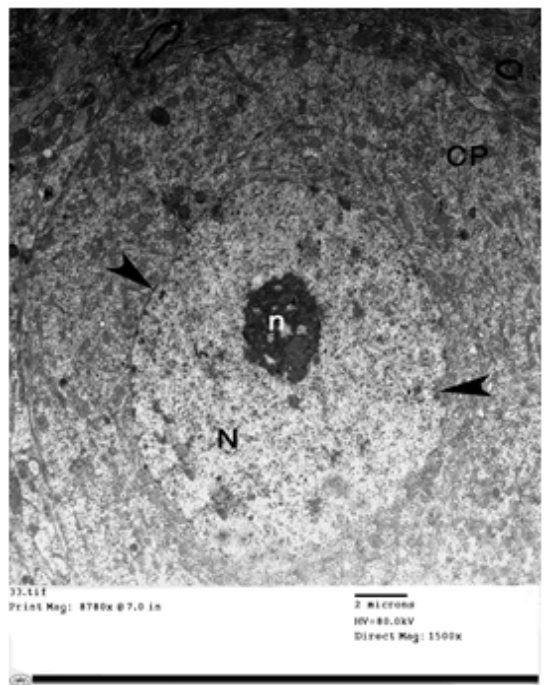

(a)

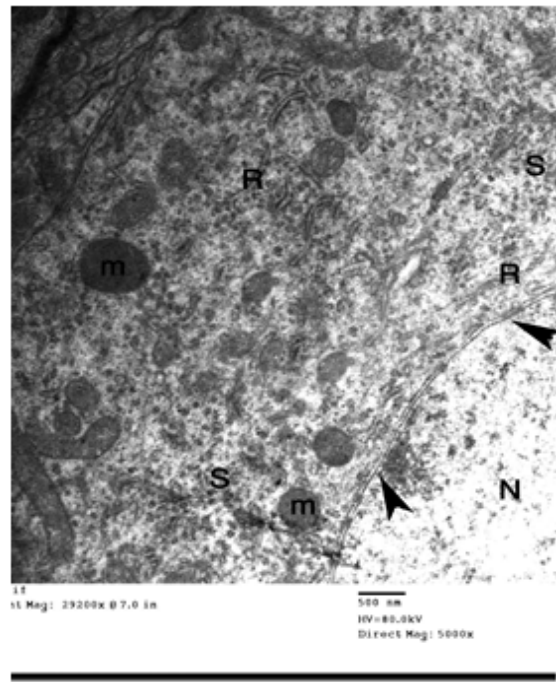

(b)

Figure 8: (a) A transmission electron micrograph of the Purkinje cell layer of the cerebellar cortex: Group I showing Purkinje cell with large indented euchromatic nuclei $(N)$, apparent nucleolus $(n)$, nuclear membrane (arrow heads), and cytoplasm (CP) (TEM, 1500x); (b) A higher magnification of the pervious image showing a part of Purkinje cell with euchromatic nucleus $(\mathrm{N})$ and nuclear membrane (arrowheads). The cytoplasm contains tubules of rough endoplasmic reticulum (R) and mitochondria $(\mathrm{m})$. Multiple free ribosomes (S) are seen (TEM, 5000x).

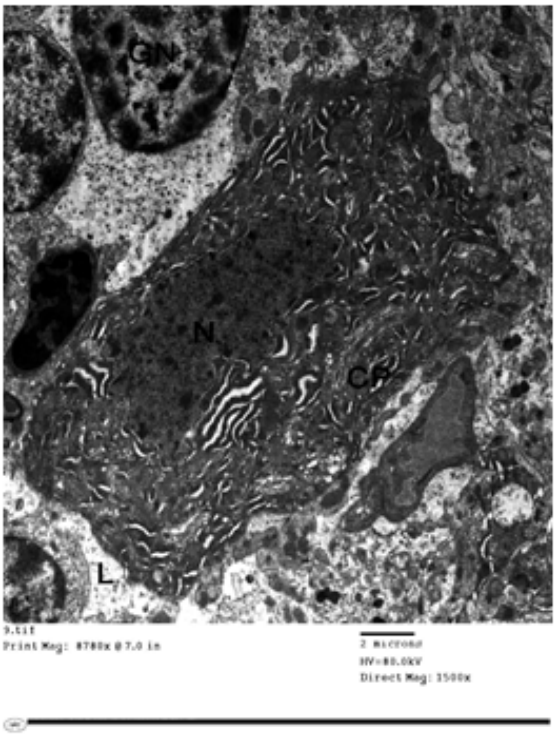

(a)

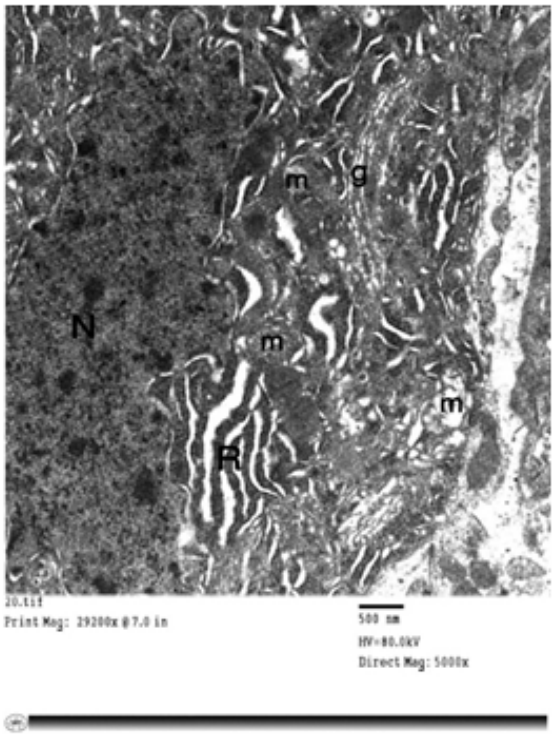

(b)

Figure 9: (a) A transmission electron micrograph of the Purkinje cell layer of the cerebellar cortex of group II showing shrunken Purkinje cell with corrugated nucleus $(\mathrm{N})$ and heterogenous cytoplasm (CP). Degenerated neuropils (L) and dark nuclei of granule cell (GN) are observed (TEM, 1500x); (b) A higher magnification of the pervious image showing a part of Purkinje cell with irregular nucleus $(\mathrm{N})$. The cytoplasm reveals disrupted mitochondria ( $\mathrm{m}$ ), dilated rough endoplasmic reticulum tubules (R) and Golgi saccules (g) (TEM, 5000×).

(Figure 8b). Groups II and III exhibited shrunken Purkinje cells with irregular nuclei and heterogenous cytoplasm. Degenerated neuropils and dark nuclei of granule cell were observed (Figures 9a and 10a). A highly magnified Purkinje cell showed irregular nucleus and dark nucleolus. Furthermore, their cytoplasm had disrupted mitochondria and dilated rough endoplasmic reticulum tubules and Golgi saccules (Figures 9b and 10b). Group IV demonstrated apparently normal Purkinje cell with euchromatic nucleus and cytoplasm, also a granule cell nucleus was seen (Figure 11a). Highly magnified Purkinje cells were apparently normal with euchromatic nucleus. The cytoplasm had mitochondria, cisternae of rough endoplasmic reticulum and free ribosomes (Figure 11b).

Granular cells layer of group I exhibited clumps of heterochromatin in the nuclei of granule cells, while the cytoplasm was thin and had free 
Citation: El-Azab NEE, El-Mahalaway AM, Sabry D (2018) Effect of Methyl Mercury on the Cerebellar Cortex of Rats and the Possible Neuroprotective Role of Mesenchymal Stem Cells Conditioned Medium. Histological and Immunohistochemical Study. Stem Cell Res Ther 8: 430. doi: $10.4172 / 2157-7633.1000430$

Page 7 of 11

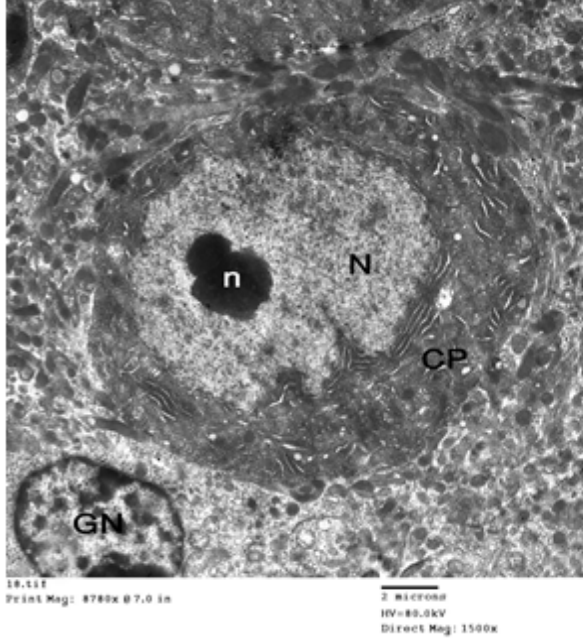

(a)

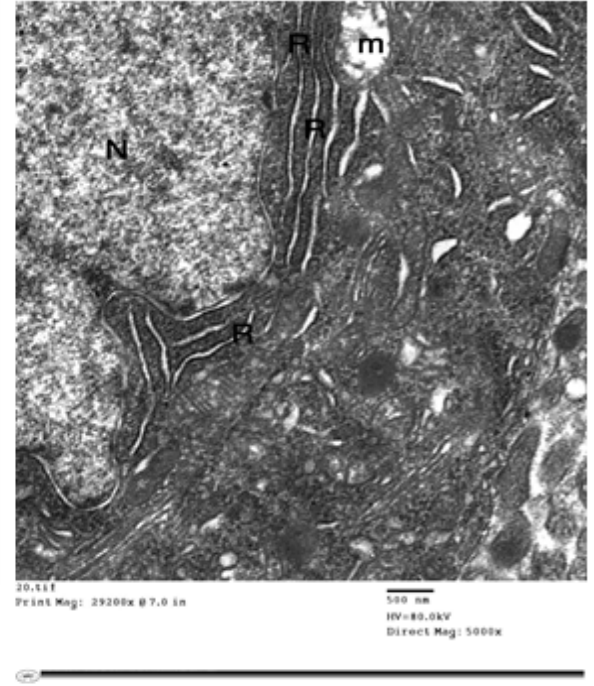

(b)

Figure 10: (a) A transmission electron micrograph of the Purkinje cell layer of the cerebellar cortex of group III showing a Purkinje cell with irregular nucleus (N), dark nucleolus ( $n$ ) and cytoplasm (CP). Notice the presence of granule cell nucleus (GN) (TEM, 1500x); (b) A higher magnification of the pervious image showing a part of Purkinje cell with irregular nucleus $(\mathrm{N})$. The cytoplasm displays disrupted mitochondria $(\mathrm{m})$ and dilated rough endoplasmic reticulum (R) (TEM, 5000×).

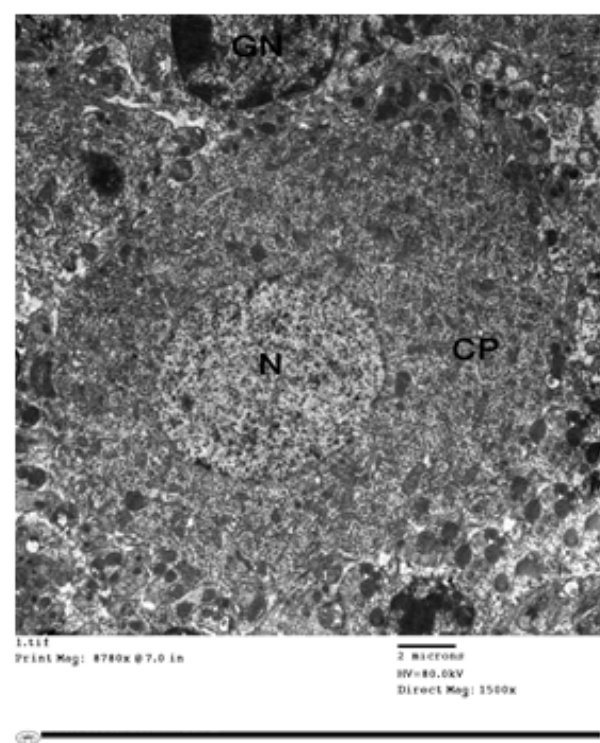

(a)

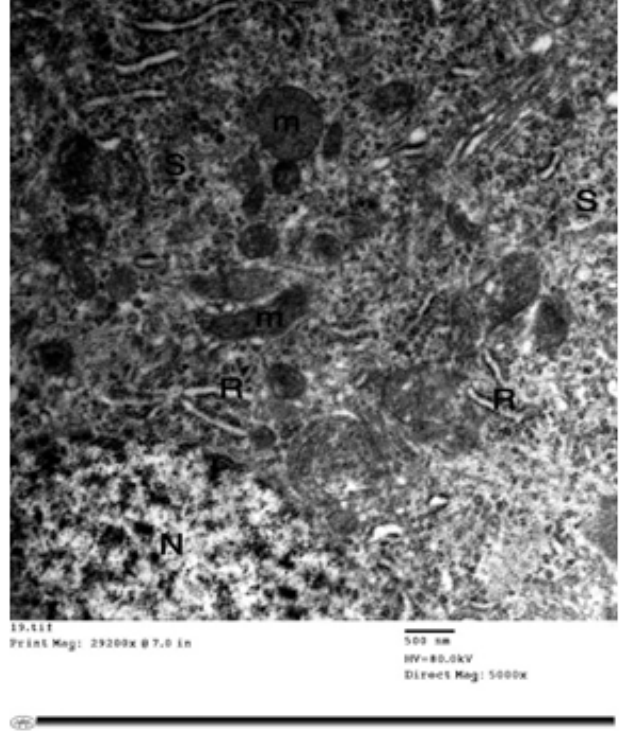

(b)

Figure 11: (a) A transmission electron micrograph of the Purkinje cell layer of the cerebellar cortex of group IV showing apparently normal Purkinje cell with euchromatic nucleus (N) and cytoplasm (CP). A part of granule cell nucleus (GN) is seen (TEM, 1500x); (b) A higher magnification of the pervious image showing a part of Purkinje cell with apparently normal euchromatic nucleus $(\mathrm{N})$. The cytoplasm contains mitochondria $(\mathrm{m})$, cisternae of rough endoplasmic reticulum $(\mathrm{R})$ and free ribosomes (S) (TEM, 5000x).

ribosomes and mitochondria (Figure 12a). Groups II and III displayed granule cells with irregular nucleus and increased condensation of heterochromatin inside their nuclei, while the cytoplasm contained degenerated mitochondria, free ribosomes, tubules of rough endoplasmic reticulum and vacuoles. Furthermore, degenerated neuropils and myelinatedfibers with degenerated, vacuolated mitochondria could be seen (Figures $12 \mathrm{~b}$ and $12 \mathrm{c}$ ). Group IV showed apparently normal granule cells with clumps of heterochromatin insidetheir nuclei, meanwhile free ribosomes and mitochondria were seen within their thin rim of cytoplasm. Also, myelinatedfiber with mitochondria in its axoplasm was seen (Figure 12d).

\section{Morphometric and statistical results}

The mean number and standard deviation $( \pm S \mathrm{SD})$ of Purkinje cells of all groups were represented in Table 1 and Histogram 1. There was a significant decrease $(\mathrm{P}<0.01)$ in groups II and III compared with group 
Citation: El-Azab NEE, El-Mahalaway AM, Sabry D (2018) Effect of Methyl Mercury on the Cerebellar Cortex of Rats and the Possible Neuroprotective Role of Mesenchymal Stem Cells Conditioned Medium. Histological and Immunohistochemical Study. Stem Cell Res Ther 8: 430. doi: $10.4172 / 2157-7633.1000430$

Page 8 of 11

I, but there was a significant increase $(\mathrm{P}<0.01)$ in mean number of Purkinje cells in group IV compared with groups II and III. Group IV showed insignificant decrease $(\mathrm{P}<0.01)$ compared with group I.

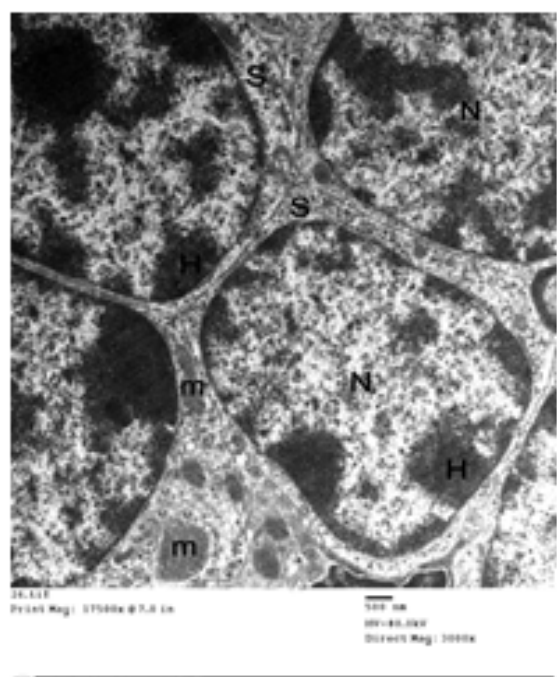

(a)

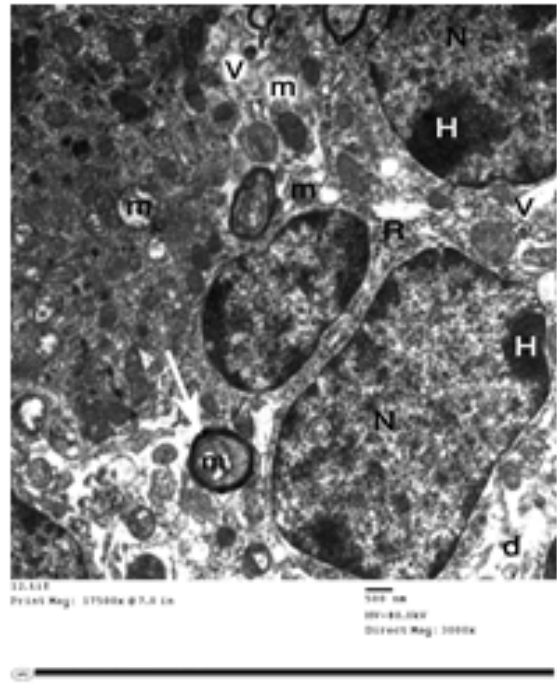

(c)
The mean area $\%$ and \pm SD of GFAP positive staining for astrocytes of all groups were represented in Table 2 and Histogram 2. There was a significant increase $(\mathrm{P}<0.01)$ of mean area $\%$ of GFAP positive staining in groups II and III compared with group I. There was a significant

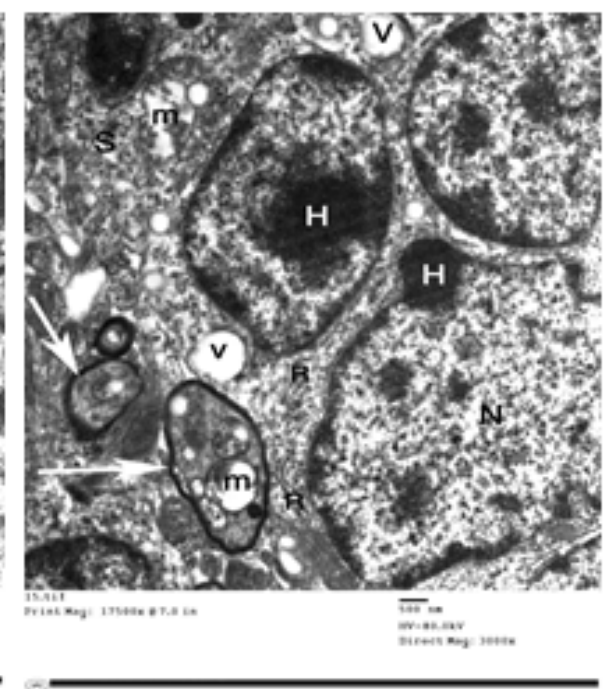

(b)

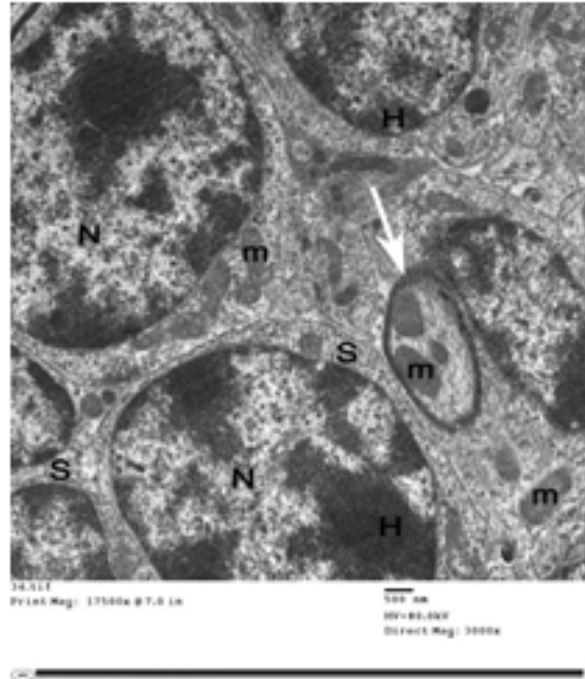

(d)

Figure 12: Transmission electron micrographs of the granular layer of the cerebellar cortex: (a) Group I showing granule cells with clumps of heterochromatin $(\mathrm{H})$ in their nuclei $(\mathrm{N})$. The cytoplasm is thin and has free ribosomes (S) and mitochondria $(\mathrm{m})(\mathrm{TEM}, 3000 \times) ;(\mathbf{b})$ Group II showing granule cells with irregular nucleus (N) and increased condensation of heterochromatin $(\mathrm{H})$. The cytoplasm contains degenerated mitochondria $(\mathrm{m})$, free ribosomes $(\mathrm{S})$, tubules of rough endoplasmic reticulum $(\mathrm{R})$ and vacuoles (V). Myelinated fibers (white arrows) with degenerated and vacuolated mitochondria (m) can be seen (TEM, 3000x); (c) Group III showing granule cells $(\mathrm{G})$ with increased condensation of heterochromatin $(\mathrm{H})$ inside their nuclei $(\mathrm{N})$. The cytoplasm contains degenerated mitochondria $(\mathrm{m})$ and vacuoles $(\mathrm{V})$. Degenerated neuropils (d) and myelinated fibers (white arrows) with degenerated and vacuolated mitochondria (m) are seen (TEM, 3000x); (d) Group IV showing apparently normal granule cells with clumps of heterochromatin $(\mathrm{H})$ inside their nuclei $(\mathrm{N})$. Free ribosomes $(\mathrm{S})$ and mitochondria $(\mathrm{m})$ are seen within their thin rim of cytoplasm. Myelinated fiber (white arrows) with mitochondria ( $m$ ) in its axoplasm is seen (TEM, 3000x).

\begin{tabular}{|l|c|c|c|c|}
\hline & Group I & Group II & Group III & Group IV \\
\hline Mean area \% & $4.98 \%$ & $1.92 \%$ & $1.94 \%$ & $4.94 \%$ \\
\hline SD & 0.1476 & 0.1687 & 0.1647 & 0.1647 \\
\hline Significance (sig.) at P<0.01 & 2,3 & 1,4 & 1,4 & 2,3 \\
\hline
\end{tabular}

Table 1: Showing the mean number and \pm SD of purkinje cells for all groups with comparison between all groups by Post Hoc LSD test.

1=sig. with group I, 2=sig. with group II, 3=sig. with group III, 4=sig. with group IV

\begin{tabular}{|l|c|c|c|c|}
\hline & Group I & Group II & Group III & Group IV \\
\hline Mean area \% & $7.49 \%$ & $40.72 \%$ & $40.27 \%$ & $13.29 \%$ \\
\hline SD & 0.524 & 1.0193 & 1.7204 & 1.4645 \\
\hline Significance (sig) at $\mathrm{P}<0.01$ & $2,3,4$ & 1,4 & 1,4 & $1,2,3$ \\
\hline
\end{tabular}

Table 2: Showing the mean area $\%$ and \pm SD of GFAP-positive staining for all groups with comparison between all groups by Post Hoc LSD test.

$1=$ sig. with group I, $2=$ sig. with group II, $3=$ sig. with group III, $4=$ sig. with group IV 
Citation: El-Azab NEE, El-Mahalaway AM, Sabry D (2018) Effect of Methyl Mercury on the Cerebellar Cortex of Rats and the Possible Neuroprotective Role of Mesenchymal Stem Cells Conditioned Medium. Histological and Immunohistochemical Study. Stem Cell Res Ther 8: 430. doi: $10.4172 / 2157-7633.1000430$

Page 9 of 11

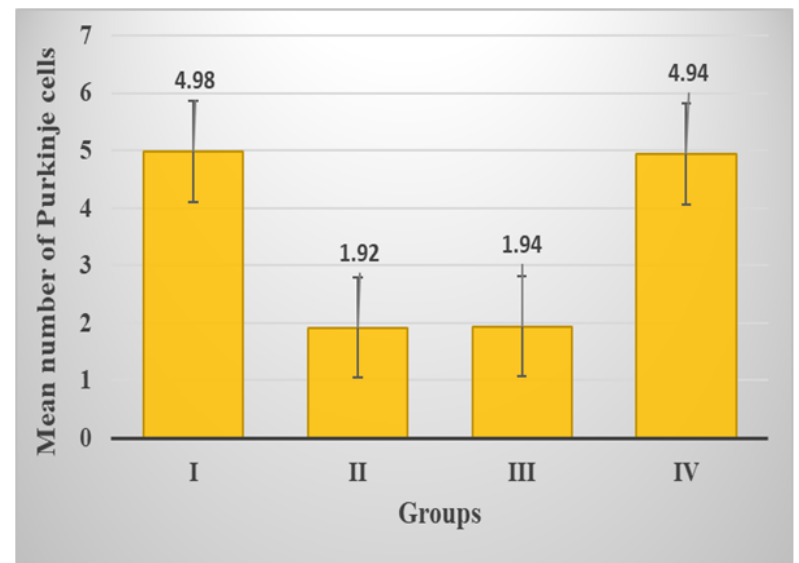

Histogram 1: Showing the mean number of purkinje cells in all experimental groups.

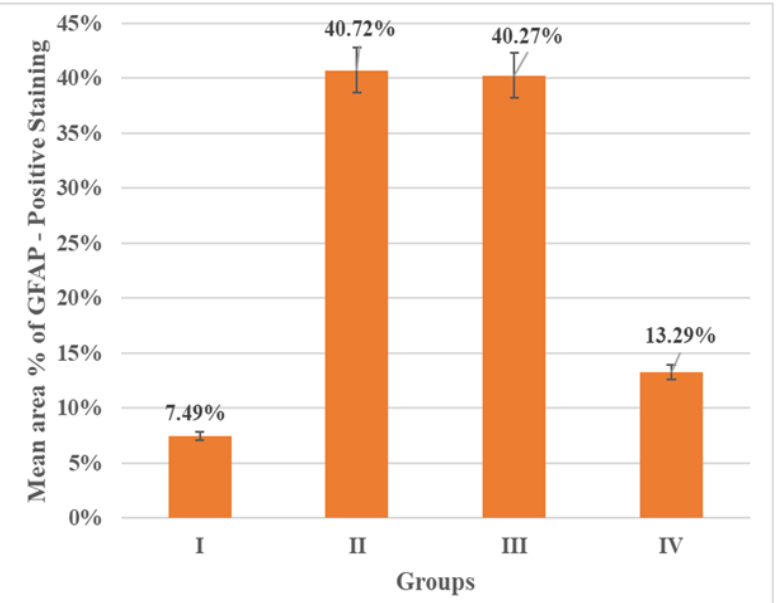

Histogram 2: Showing the mean area \% of GFAP-positive staining in all groups.

decrease $(\mathrm{P}<0.01)$ of GFAP positive staining in group IV compared with groups II and III, but it remained significantly increased compared with group I.

\section{Discussion}

Environmental and occupational pollution by heavy metals as $\mathrm{Me}$ $\mathrm{Hg}$ result in dangerous health problems to human and animals through progressive accumulation in their bodies $[25,26]$.

The light and immunohistochemical examination of cerebellar sections of group II (Me $\mathrm{Hg}$ treated group) and group III (Me $\mathrm{Hg}$ and DMEM treated group) revealed several changes as areas of degeneration in the molecular layer. The Purkinje cells had dark stained nuclei with eosinophilic cytoplasm and some of them are lost leaving empty spaces. Granular layer appeared thin and contained many apoptotic cells. Furthermore, there was a significant decrease $(\mathrm{P}<0.01)$ in the mean number of Purkinje cells and a significant increase $(\mathrm{P}<0.01)$ of expression of GFAP immunostaining in the neuroglial cells and their processes.

These results agreed with numerous studies $[7,27]$ that mentioned that $\mathrm{Me} \mathrm{Hg}$ were neurotoxic and induced neuronal degeneration, neuronal necrosis, neuronal chromatolysis, and axonal demyelination. Another scientist $[28,29]$ reported that the most sensitive layer in the cerebellar cortex to $\mathrm{Me} \mathrm{Hg}$ poisoning was the Purkinje cells, which reacted to these toxic elements by undergoing degeneration and were finally lost from their place in the Purkinje cell layer. The previous results clarified that $\mathrm{Me} \mathrm{Hg}$ can cross blood brain barrier [30].

GFAP is an intermediate filament protein and the specific marker for mature astrocytes, which defined their shape and movements and specified the synaptic efficiency in the central nervous system [31]. Features of activation of astrocytes were evident in the present study by increasing expression of GFAP because of neuronal damage caused by $\mathrm{Me} \mathrm{Hg}$ that might take place as a result of a compensatory mechanism after neurodegeneration. These results in our research were in accordance with previous researches of other scientists [31-33], who explained that any mechanical, chemical, or degenerative insults to the brain stimulate astrocytes to become reactive and then abide by a typical process called astrogliosis. Astrogliosis is recognized through the immediate synthesis of GFAP and an increase of immunostaining with the GFAP antibody.

Electron microscopic examination of cerebellar sections of group II and group III showed thinning, splitting, and apparent decrease in the number of myelinated nerve axons with swollen disrupted mitochondria, while Purkinje cells were shrunken with irregular nuclei and heterogenous cytoplasm and had disrupted mitochondria, dilated rough endoplasmic reticulum tubules and Golgi saccules. Furthermore, the granule cells had irregular nucleus and increased condensation of heterochromatin inside their nuclei.

Our findings are identical with previous researches [9,25] which proved that accumulation of mercury compounds in many regions of the Central Nervous System (CNS) as olfactory bulbs, cerebral hemispheres, cerebellum, medulla oblongata and spinal cord leads to degeneration and inhibition of enzymes followed by losing of brain functions. These results were supported by investigators [34] that described Me Hginhibition of cell division and migration both in vivo and in vitro.

Some previous studies $[9,35]$ mentioned that $\mathrm{Me} \mathrm{Hg}$ is a strong toxin that affects enzymes, cell membrane function and neuron delivery materials leading to oxidative stress, lipid peroxidation, and mitochondria dysfunction as well as disturbance of synaptic transmission and alteration of microtubule composition and amino acid transport of the brain.

Other reporters [36] explained that the way of action of $\mathrm{Me} \mathrm{Hg}$ induced neurotoxicity mediated through damaging of Blood-Brain Barrier (BBB) and alteration of calcium homeostasis and glutamate homoeostasis; moreover it helps in induction of apoptosis or necrosis.

Cerebellar cortex sections of group III showed the same histological and immunohistochemical alterations encountered with group II without any improvement. These results coincide with other previous researches $[16,20]$. Serum-free DMEM was used as a control medium. It was utilized in MSCs - CM preparation. DMEM was injected into rats after $\mathrm{Me} \mathrm{Hg}$ administration to exclude any beneficial curative effect of it.

$\mathrm{CM}$ is a promising novel approach for repairing of wound and tissue regeneration and is also a remedy for neurological diseases as cerebral injury, ischemia and stroke through reducing neuronal cells injuries and enhancing the neuronal glial viability $[37,38]$. 
Citation: El-Azab NEE, El-Mahalaway AM, Sabry D (2018) Effect of Methyl Mercury on the Cerebellar Cortex of Rats and the Possible Neuroprotective Role of Mesenchymal Stem Cells Conditioned Medium. Histological and Immunohistochemical Study. Stem Cell Res Ther 8: 430. doi: $10.4172 / 2157-7633.1000430$

Page 10 of 11

Group IV (CM treated group) of current research showed marked improvement of the histological structure for all layers of the cerebellar cortex. There was a significant increase $(\mathrm{P}<0.01)$ in mean number of Purkinje cells and a significant decrease $(\mathrm{P}<0.01)$ of GFAP positive immunostaining compared with groups II and III. Ultrastructural examination showed nearly normal Purkinje cells with euchromatic nucleus. Normal granule cells with free ribosomes and mitochondria were visualized inside their thin rim of cytoplasm. Also, myelinated fibers with mitochondria in their axoplasm were seen.

The previous results agreed with those of other researchers [16,39], who in their studies on the CM showed remyelination of the CNS and reduced astrogliosis, which were supported by significant decrease of GFAP positive immunostaining. It is accepted by many colleagues $[16,38,40]$ that MSCs - CM could improve angiogenesis by its effect on VEGF and resolve inflammation through promoting secretion of antiinflammatory substances, which inhibit fibrosis, apoptosis and necrosis after acute organ injury. Furthermore, it contains various growth factors i.e., Vascular Endothelial Growth Factor (VEGF), Platelet Derived Growth Factor (PDGF), Insulin Like Growth Factor-1 (IGF1), Neural Growth Factor (NGF), and Brain Derived Neurotrophic Factor (BDNF). Moreover CM contains anti-inflammatory cytokines i.e., Transforming Growth Factor- $\beta 1$ (TGF- $\beta 1$ ) and some Interleukins (IL) as IL-6, IL-10, IL-27, IL-17E and IL-13 [12]. Several researches [41] have appeared supporting the neuroprotective and neurotrophic effects of MSC- CM which contains number of neurothophic factors and has a vital role in modulation of the neurogenic niche. In addition MSCs - CM can modulate the inflammatory environment, enhance vascularization of the regenerating site, increase thickness of the myelin sheaths, accelerate fibre regeneration and reduce of fibrotic scaring and improve fibre organization.

Some former workers [42] reported that MSCs - CM have several benefits over MSCs as they can be manufactured, freeze-dried, packaged, and transported more easily than stem cells.Moreover, $\mathrm{CM}$ does not contain living cells, so there is no need to do donor recipient matching to avoid rejection.

The neuroprotective effects of MSCs - CM could be explained by its capacity to reduce oxidative stress and inhibit the release of both 3-Nitrotyrosine (3-NT) and Nitric Oxide Synthase (iNOS). Moreover, nerve growth factor and brain-derived neurotrophic factor, which decrease reactive astrogliosis were detected in significant amounts in MSCs - CM derived from bone marrow of rats $[16,42]$.

\section{Conclusion}

$\mathrm{Me} \mathrm{Hg} \mathrm{exposure} \mathrm{leads} \mathrm{to} \mathrm{oxidative} \mathrm{stress} \mathrm{and} \mathrm{degenerative} \mathrm{changes}$ on cerebellar cortex. MSCs - CM has neuroprotective effects. It is a very promising approach as it is easily manufactured, freeze-dried, packaged, and transported. However, we recommend further researches later employing multiple and longer periods of treatment to evaluate the persistence of its effectiveness on the long term for clinical applications.

\section{Conflict of interest}

None

\section{References}

1. Abdel-Hafez AMM, Mohamed NA (2013) Effect of selenium in ameliorating the effect of induced perinatal hypothyroidism on postnatal rat cerebellar cortex development: a histological and immunohistochemical study. EJH 36: 660-680.

2. Selim AS, Selim AO (2013) Effect of streptozotocin-induced diabetes mellitus on the cerebellar cortex of adult male albino rats: histological and immunohistochemical study. EJH 36: 103-113.

3. Hussine EM, El-Kott AF (2013) Histological and flow cytometrical effects of white tea extract against mercury-induced hepatotoxicity in mice. ACB 2: 43-51.

4. Abdella EM (2017) Protective effects of white tea extract against mercuric chloride induced hepatotoxicity in mice. IJPSR 8: 603-610.

5. Mahmoud OM, Al Badawi MH, Salem NA (2014) Role of Ginseng on mercury chloride-induced testicular lesions in adult albino rat: a histological and immunohistochemical study. EJH 37: 506-513.

6. Dardouri K, Haouem S, Gharbi I, Sriha B, Haouas Z, et al. (2016) Combined effects of $\mathrm{Cd}$ and $\mathrm{Hg}$ on liver and kidney histology and function in wistar rats. $J$ Agric Chem Environ 5: 159-169.

7. Christinal J, Sumathi T (2013) Effect of Bacopa monniera extract on methy mercury-induced behavioral and histopathological changes in rats. Biol Trace Elem Res 155: 56-64. [PubMed]

8. Saad TM (2013) Effect of curcumin on some heavy metals induced renal and testicular injuries in male rats. The Egyptian Journal of Hospital Medicine 53: 770-781.

9. Wang H, Chen B, He M, Yu X, Hu B (2017) Selenocystine against methyl mercury cytotoxicity in HepG2 cells. Scientific Reports 7: 1-8. [PubMed]

10. Salem MY, El-Azab NE, Helal OK, Metwaly HG, Bayoumi HE (2015) Does selenium improve the stem cell therapeutic effect on isoproterenol-induced myocardial infarction in rats? A histological and immunohistochemical study. EJH 38: 679-691.

11. Sayed WM, Rashed LA (2016) Therapeutic role of bone marrow-derived mesenchymal stem cells in cyclophosphamide-induced cardiotoxicity in adult male albino rat: a morphological and immunohistochemical study. EJH 39: 281 293.

12. Pawitan JA (2014) Prospect of stem cell conditioned medium in regenerative medicine. Biomed Res Int 2014: 1-14.

13. Diomede F, Gugliandolo A, Scionti D, Merciaro L, Mazzon E, et al. (2018) Bio therapeutic effect of gingival stem cells conditioned medium in bone tissue restoration. Int J Mol Sci 19: 329.

14. Gama KB, Santos DS, Evangelista AF, Silva DN (2018) Conditioned medium of bone marrow-derived mesenchymal stromal cells as a therapeutic approach to neuropathic pain: a preclinical evaluation. Stem Cells Int 2018: 12. [PubMed]

15. Salem M, Helal O, Metwaly H, El-Hady A, Ahmed S (2017) Histological and immunohistochemical study of the role of stem cells, conditioned medium and microvesicles in treatment of in treatment of experimentally induced acute kidney injury in rats. Journal of Medical Histology 1: 69-83.

16. El-Maadawi ZM (2017) Conditioned medium derived from salidroside-pretreated mesenchymal stem cell culture ameliorates mouse lipopolysaccharide-induced cerebral neuroinflammation - histological and immunohistochemical study. Int $\mathrm{J}$ Stem Cells 10: 60-68. [PubMed]

17. Sefati N, Norouzian M, Abbaszadeh H, Abdollahifar M, Amini A, et al. (2018) Effects of bone marrow mesenchymal stem cells-conditioned medium on tibial partial osteotomy model of fracture healing in hypothyroidism rats. Iran Biomed J 22: 90-98. [PubMed]

18. Xing L, Cui R, Peng L, Ma J, Chen X, et al. (2014) Mesenchymal stem cells not conditioned medium, contribute to kidney repair after ischemia- reperfusion injury. J Stem Cell Res Ther 5: 101-112. [PubMed]

19. Iwai-Shimada M, Takahashi T, Kim MS, Fujimura M, Ito $H$, et al. (2016) Methylmercury induces the expression of TNF- $\alpha$ selectively in the brain of mice. Sci Rep 6: 1-8. [PubMed]

20. Yeng $\mathrm{CH}$, Chen PJ, Chang HK, Lo WY, Wu CC, et al. (2016) Attenuating spinal cord injury by conditioned medium from human umbilical cord blood-derived CD34+ cells in rats. Taiwan J Obstet Gynecol 55: 85-93. [PubMed]

21. Abd El Zaher F, El Shawarby A, Hammouda G, Bahaa N (2017) Role of mesenchymal stem cells versus their conditioned medium on cisplatin-induced acute kidney injury in albino rat. A histological and immunohistochemical study. EJH 40: 37-51.

22. Bancroft JD, Layton C (2013) The hematoxylin and eosin, connective and mesenchymal tissues with their stains. In: Suvarna SK, Layton C, Bancroft JD editors. Bancroft's theory and practice of histological techniques. 7th Edn. Philadelphia: Churchill Livingstone, pp. 173-212. 
Citation: El-Azab NEE, El-Mahalaway AM, Sabry D (2018) Effect of Methyl Mercury on the Cerebellar Cortex of Rats and the Possible Neuroprotective Role of Mesenchymal Stem Cells Conditioned Medium. Histological and Immunohistochemical Study. Stem Cell Res Ther 8: 430. doi: $10.4172 / 2157-7633.1000430$

Page 11 of 11

23. Jackson P, Blythe D (2013) Immunohistochemical techniques. In: Suvarna SK Layton C, Bancroft JD (eds.) Theory and practice of histological techniques. 7th Edn. Philadelphia: Churchill Livingstone of Elsevier, pp. 381-434.

24. Hayat MA (2000) Chemical fixation. In: Hayat MA (ed.) Principles and techniques of electron microscopy: biological applications. 4th ed.: Edinburg, UK: Cambridge University Press, pp. 4-85.

25. Rao MV, Purohit AR (2011) Neuroprotection by melatonin on mercury induced toxicity in the rat brain. Pharmacology \& Pharmacy 2: 375-385.

26. Oriquat GA, Saleem TH, Naik RR, Moussa SZ, Al-Gindy RM (2012) A subchronic toxicity study of mercuric chloride in the rat. Jordan J Biol Sci 5: 141 146

27. Abdel-Salam AM, El-Agamy El, Zeitoun MM, Mohammed F, Mousa HM (2013) Immunoprophylactic and protective effects of synbiotic fermented mare's milk against mercury toxicity in rats. The Journal of Food Technology 105: 171-178.

28. Ibegbu AO, Abdulrazaq A, Micheal A, Daniel B, Sadeeq A, et al. (2014) Histomorphological effect of ascorbic acid on mercury chloride-induced changes on the cerebellum of adult wistar rats. J Morphol Sci 31: 219-224.

29. Sherin J, Sumathi T (2016) Neurotoxic effects of gestational exposure of methy mercury on different brain regions of F1 generation; neurobehavioural, biochemical and histological study during weaning period of rat. IJTPR 8: 83-93.

30. Ranjan B, Husain SMD, Kumar K, Maheshwari TP (2015) Comparative study of histo-pathological effects of mercury on cerebrum, cerebellum and hippocampus of adult albino rats. AIMDR 1: 21-24.

31. Laag EM, Elaziz HOA (2013) Effect of aflatoxin-B1 on rat cerebellar cortex: ligh and electron microscopic study. EJH 36: 601-610.

32. Hashem HE, El-Din Safwat MD, Algaidi S (2012) The effect of monosodium glutamate on the cerebellar cortex of male albino rats and the protective role of vitamin C (histological and immunohistochemical study). J Mol Hist 43: 179186. [PubMed]

33. Omar IA, Farag EA, Yousry MM (2016) The possible protective effect of piperine versus vitamin $\mathrm{C}$ on monosodium glutamate-induced cerebellar toxicity in adult male rats: a histological and immunohistochemical study. EJH 39: 362-371.
34. Azevedo BF, Furieri LB, Pecanha FM, Wiggers GA, Vassallo PF, et al. (2012) Toxic Effects of Mercury on the Cardiovascular and Central Nervous Systems. J Biomed Biotechnol 2012: 1-11. [PubMed]

35. Hong YS, Kim YM, Lee KE (2012) Methylmercury exposure and health effects J Prev Med Public Health 45: 353-363. [PubMed]

36. Takahashi T, Fujimura M, Koyama M, Kanazawa M, Usuki F, et al. (2017) Methylmercury causes blood-brain barrier damage in rats via upregulation of vascular endothelial growth factor expression. PLoS ONE 12: e0170623. [PubMed]

37. Tajiri N, Acosta SA, Shahaduzzaman M, Ishikawa H, Shinozuka S, et al. (2014) Intravenous transplants of human adipose-derived stem cell protect the brain from traumatic brain injury-induced neurodegeneration and motor and cognitive impairments: Cell graft biodistribution and soluble factors in young and aged rats. J Neurosci 34: 313-326. [PubMed]

38. Xu X, Li L, Li X, Shi Q, Ju X (2017) Mesenchymal stem cell conditioned medium alleviates oxidative stress injury induced by hydrogen peroxide via regulating miR143 and its target protein in hepatocytes. BMC Immunol 51: 1-14. [PubMed]

39. Shimojima C, Takeuchi H, Jin S, Parajuli P, Hattori H (2016) Conditioned medium from the stem cells of human exfoliated deciduous teeth ameliorates experimental autoimmune encephalomyelitis. J Immunol 196: 4164-4171. [PubMed]

40. Sanchooli T, Norouzian M, Ardeshirylajimi A, Ghoreishi S (2017) Adipose derived stem cells conditioned media in combination with bioceramic-collagen scaffolds improved calvarial bone healing in hypothyroid rats. Iran Red Crescent Med J 19: 1-11.

41. Vizoso FJ, Eiro N, Cid S, Schneider J, Fernandez RP (2017) Mesenchyma stem cell secretome: toward cell-free therapeutic strategies in regenerative medicine. Int J Mol Sci 18: 1-24. [PubMed]

42. Mete M, Aydemir I, Ünsal U, Duransoy Y, Tuğlu I, et al. (2016) Neuroprotective effects of bone marrow-derived mesenchymal stem cells and conditioned medium in mechanically injured neuroblastoma cells. Turk J Med Sci 46: 1900 1907. 